\title{
Staffing and facilities in cardiology in England and Wales July 1982 Second biennial survey
}

\author{
DOUGLAS CHAMBERLAIN, LINDA BAILEY, RICHARD EMANUEL, MICHAEL OLIVER
}

From the Centre for Medical Research, University of Sussex, in collaboration with the Cardiology Committee, Royal College of Physicians of London, and the British Cardiac Society

The first survey on career prospects in cardiology in England and Wales was started in 1979 and published in 1981.1 The purpose was twofold: to obtain accurate information on the appropriate ratio between the number of consultant posts and senior registrars in training and to identify districts which might be poorly endowed with expertise and facilities in the specialty. In both respects the survey identified serious deficiencies. Recognition of the problems has already influenced attitudes both within the profession and among those, responsible for its administration.

A decision was made by the cardiology committee of the Royal College of Physicians and by the council of the British Cardiac Society that the situation should be monitored biennially at least until adequate provision for cardiology becomes more generally available. A second survey has therefore been conducted of both staffing and facilities available in the health districts of England and Wales relating to 1 July 1982 . We report a summary of our findings together with additional information made available to us by colleagues in Scotland and Northern Ireland.

\section{Methods of inquiry}

A cardiologist in each health region of England and Wales was sent a list of districts in his locality and asked to suggest a physician in each who might be willing to complete a questionnaire. Some districts are large with hospitals which operate autonomously; in such cases two contacts were approached.

The questionnaire was substantial and comprised 19 sections relating to consultant staff, senior registrars, technical staff, referral patterns, facilities, and equipment. Cardiovascular physicians (cardiologists)

Accepted for publication 15 September 1983 were defined as physicians who have both a special interest and an appropriate training in the specialty, though these criteria were not specified further. We made a distinction between those who spend virtually all of their professional time in cardiology and those with a major commitment to the specialty (occupying more than $40 \%$ of their time) but with additional responsibilities in general medicine.

As in our previous survey, about half our questionnaires were returned promptly. When necessary, second and third reminders were sent and finally telephone contact was made until all information had been received for each health district. The level of cooperation was generally excellent.

The complete data were stored in a main frame computer (Vax III) to facilitate analysis and subsequent comparisons. They were then assembled for each region and submitted under confidential cover to our original regional advisors for scrutiny as a guard against inadvertent errors. Disagreements between regional advisors and our district contacts were resolved by further inquiries. We believe that the data we have collected are as complete and as accurate as can reasonably be expected without the availability of first hand local knowledge.

Similar surveys were conducted at about the same time by colleagues both in Scotland and Northern Ireland. Some of the data they have made available to us are presented as an appendix so that a comprehensive picture is available on consultant staffing for the whole of the United Kingdom. Additional information on senior registrars was requested by the chairman of the specialty subcommittee for higher medical training. We therefore sent a supplementary questionnaire to senior registrars identified as being in post in July 1982 and to those appointed between that date and 18 April 1983, but these data are not complete and are not included in this report. 
A summary of the data collected is presented in Tables 1 to 8 and in Appendices I and II. In addition, analyses which have been compiled under individual health districts can be made available to those with a legitimate interest in the provision of cardiological services. Some information, notably individual names of consultants and senior registrars with associated retirement or contract expiry dates, is regarded as confidential and will not be divulged except as composite data in tables.

\section{Comment}

This present survey is more comprehensive than the first ${ }^{1}$ in that details are provided not only of medical staff at consultant and senior registrar level but also of technicians and facilities available in all the regions of England and Wales. The format of tables has also been changed; while this makes direct comparison more difficult, they now provide more information and will form a useful basis for identifying trends from subsequent surveys.

We consider the use of an index date (July 1982) to be essential. Much confusion arose when forms were sent for checking because new information was added. While our data are not strictly current they do represent the situation in July 1982 with, we believe, the best accuracy which can be achieved in a survey of this type.

Table 1 shows the total numbers of cardiovascular physicians in each region. The identification of physicians spending virtually all of their time in cardiology was-as before-readily achieved. It is more difficult to identify physicians with a major interest in the specialty because an arbitrary division has to be made. The questionnaire asked for the names of physicians within each health district "who have special experience and a major interest in cardiology which occupies more than $40 \%$ of their time." We do not believe that this was interpreted differently from the corresponding question in our 1980 survey. Broadly, therefore, differences are real rather than methodological. The number of consultant posts has increased overall by 27 in England and Wales (223 to 250). We have identified seven additional posts in full time adult or paediatric cardiology and 20 more posts for cardiovascular physicians with a major interest. We are aware of four districts in which cardiovascular physicians with a major interest have been replaced by physicians with other skills; but, overall, the creation of new posts and the changed designation of new appointments into existing posts have produced a favourable balance for cardiology. When Scotland and Northern Ireland are included, the total number of posts for cardiovascular physicians (as defined in the survey) was 308.

Table 2 shows the anticipated dates of retirements. In the 1980 survey we assumed that retirement would occur at the age of 65 , but on this occasion we took into account any expressed intention to retire early.

Table 1 Number of cardiovascular physicians in post (1 fuly 1982) for each health region in England and Wales

\begin{tabular}{|c|c|c|c|c|c|c|c|c|c|}
\hline \multirow[t]{2}{*}{ Region and population } & \multirow[t]{2}{*}{$\begin{array}{l}\text { No of health } \\
\text { districts }\end{array}$} & \multirow[t]{2}{*}{$\begin{array}{l}\text { Major } \\
\text { centres }\end{array}$} & \multicolumn{3}{|c|}{$\begin{array}{l}\text { Physicians } \\
\text { Full time cardiology }\end{array}$} & \multicolumn{3}{|c|}{$\begin{array}{l}\text { Physicians } \\
\text { Major interest }\end{array}$} & \multirow[t]{2}{*}{$\begin{array}{l}\text { No of physicians } \\
\text { engaged in cardiology }\end{array}$} \\
\hline & & & Adult & Paediatric & Both & Adult & Paediatric & Both & \\
\hline \multirow{18}{*}{$\begin{array}{l}\text { East Anglia } 1863100 \\
\text { Mersey } 2458000 \\
\text { Northern } 3078000 \\
\text { North East Thames } \\
3772000 \\
\text { North West Thames } \\
3460000 \\
\text { North Western } 4063000 \\
\text { Oxford } 2340000 \\
\text { South East Thames } \\
3544000 \\
\text { South West Thames } \\
2879000 \\
\text { South Western } 3029000 \\
\text { Trent } 4517000 \\
\text { Wessex } 2744000 \\
\text { West Midlands } 5161000 \\
\text { Yorkshire } 3577000 \\
\text { Wales } 2808200 \\
\text { National Heart and } \\
\text { Chest and Great } \\
\text { Ormond Street } \\
\text { Hospitals } 0\end{array}$} & 8 & 1 & 0 & 0 & 3 & 6 & 0 & 0 & 9 \\
\hline & 10 & 1 & 4 & 2 & 0 & 2 & 1 & 0 & 9 \\
\hline & 16 & 1 & 7 & 2 & 0 & 8 & & & \\
\hline & 16 & 3 & 7 & 0 & 4 & 9 & 0 & 1 & 21 \\
\hline & & & & & & & & & \\
\hline & 15 & 4 & 9 & 2 & 3 & 7 & 1 & 1 & 23 \\
\hline & $\begin{array}{rr}0 & 19 \\
8\end{array}$ & $\begin{array}{l}3 \\
1\end{array}$ & $\begin{array}{l}5 \\
3\end{array}$ & $\begin{array}{l}1 \\
0\end{array}$ & $\begin{array}{l}3 \\
0\end{array}$ & $\begin{array}{r}14 \\
5\end{array}$ & $\begin{array}{l}0 \\
1\end{array}$ & $\begin{array}{l}0 \\
0\end{array}$ & $\begin{array}{r}23 \\
9\end{array}$ \\
\hline & 15 & 4 & & & & & & & \\
\hline & 10 & 4 & 11 & 2 & 0 & 7 & 0 & 1 & 21 \\
\hline & 13 & 1 & 3 & 0 & 2 & 4 & 0 & 0 & 8 \\
\hline & 011 & 1 & 2 & 1 & 1 & 10 & 0 & 0 & 14 \\
\hline & 12 & 2 & 0 & 0 & 5 & 9 & 1 & 1 & 16 \\
\hline & 10 & 1 & 2 & 1 & 0 & 6 & 0 & 0 & 9 \\
\hline & 022 & 3 & 7 & 1 & 4 & 10 & 0 & 1 & 23 \\
\hline & 17 & 3 & 7 & 2 & 1 & 9 & 0 & 0 & 19 \\
\hline & 9 & 1 & 3 & 0 & 1 & 6 & 0 & 0 & 10 \\
\hline & & & & & & & & & \\
\hline & 5 & 4 & 12 & 4 & 2 & 0 & 0 & 0 & 18 \\
\hline Total & 206 & 34 & 82 & 18 & 29 & 112 & 4 & 5 & 250 \\
\hline
\end{tabular}

$\star$ The National Heart and Chest Hospitals and Great Ormond Street do not comprise a region with districts. They are administered separately as independent special health authorities. 
Table 2 Number of retirements expected each year for cardiooascular physicians in post at 1 fuly 1982

\begin{tabular}{|c|c|c|c|c|c|c|c|c|c|}
\hline \multirow[t]{2}{*}{ Year } & \multicolumn{4}{|c|}{ Full time cardiology } & \multicolumn{4}{|c|}{ Major interest cardiology } & \multirow[t]{2}{*}{ Grand total } \\
\hline & $A$ & $P$ & $\boldsymbol{B}$ & Total & $A$ & $\boldsymbol{P}$ & $\boldsymbol{B}$ & Total & \\
\hline $\begin{array}{l}1983 \\
1984 \\
1985 \\
1986 \\
1987 \\
1988 \\
1989 \\
1990 \\
1991 \\
1992 \\
1993 \\
1994 \\
1995 \\
1996 \\
1997 \\
1998 \\
1999 \\
2000 \\
2001 \\
2002 \\
2003 \\
2004 \\
2005 \\
2006 \\
2007 \\
2008 \\
2009 \\
2010 \\
2011 \\
2012 \\
2013 \\
2014 \\
2015\end{array}$ & $\begin{array}{l}1 \\
1 \\
3 \\
6 \\
2 \\
3 \\
1 \\
2 \\
2 \\
1 \\
2 \\
1 \\
3 \\
1 \\
2 \\
4 \\
1 \\
4 \\
4 \\
3 \\
3 \\
4 \\
5 \\
1 \\
2 \\
4 \\
2 \\
4 \\
2 \\
4 \\
4 \\
0 \\
0\end{array}$ & $\begin{array}{l}0 \\
1 \\
1 \\
1 \\
0 \\
1 \\
1 \\
0 \\
0 \\
0 \\
0 \\
0 \\
1 \\
0 \\
0 \\
0 \\
1 \\
1 \\
1 \\
0 \\
1 \\
2 \\
3 \\
0 \\
0 \\
1 \\
0 \\
1 \\
1 \\
0 \\
0 \\
0 \\
0\end{array}$ & $\begin{array}{l}0 \\
3 \\
0 \\
1 \\
1 \\
2 \\
3 \\
1 \\
0 \\
1 \\
0 \\
0 \\
1 \\
2 \\
1 \\
2 \\
1 \\
1 \\
0 \\
2 \\
0 \\
0 \\
0 \\
1 \\
1 \\
1 \\
2 \\
0 \\
0 \\
2 \\
0 \\
0 \\
0\end{array}$ & $\begin{array}{l}1 \\
5 \\
4 \\
8 \\
3 \\
6 \\
5 \\
3 \\
2 \\
2 \\
2 \\
1 \\
5 \\
3 \\
3 \\
6 \\
3 \\
6 \\
5 \\
5 \\
4 \\
6 \\
8 \\
2 \\
3 \\
6 \\
4 \\
5 \\
3 \\
6 \\
4 \\
0 \\
0\end{array}$ & $\begin{array}{l}2 \\
3 \\
1 \\
2 \\
3 \\
3 \\
1 \\
2 \\
1 \\
4 \\
2 \\
4 \\
1 \\
3 \\
3 \\
5 \\
9 \\
4 \\
5 \\
8 \\
4 \\
4 \\
4 \\
1 \\
6 \\
6 \\
3 \\
7 \\
0 \\
5 \\
0 \\
1 \\
3\end{array}$ & $\begin{array}{l}0 \\
0 \\
0 \\
0 \\
0 \\
0 \\
0 \\
0 \\
0 \\
0 \\
0 \\
0 \\
1 \\
0 \\
0 \\
0 \\
0 \\
0 \\
0 \\
1 \\
0 \\
0 \\
0 \\
0 \\
0 \\
0 \\
1 \\
1 \\
0 \\
0 \\
0 \\
0 \\
0\end{array}$ & $\begin{array}{l}0 \\
0 \\
0 \\
1 \\
0 \\
0 \\
0 \\
0 \\
0 \\
0 \\
0 \\
0 \\
0 \\
0 \\
0 \\
0 \\
0 \\
1 \\
0 \\
0 \\
1 \\
0 \\
0 \\
0 \\
0 \\
2 \\
0 \\
0 \\
0 \\
0 \\
0 \\
0 \\
0\end{array}$ & $\begin{array}{l}2 \\
3 \\
1 \\
3 \\
3 \\
3 \\
1 \\
2 \\
1 \\
4 \\
2 \\
4 \\
2 \\
3 \\
3 \\
5 \\
9 \\
5 \\
5 \\
9 \\
5 \\
4 \\
4 \\
1 \\
6 \\
8 \\
4 \\
8 \\
0 \\
5 \\
0 \\
1 \\
3\end{array}$ & $\begin{array}{r}3 \\
8 \\
5 \\
11 \\
6 \\
9 \\
6 \\
5 \\
3 \\
6 \\
4 \\
5 \\
7 \\
6 \\
6 \\
11 \\
12 \\
11 \\
10 \\
14 \\
9 \\
10 \\
12 \\
3 \\
9 \\
14 \\
8 \\
13 \\
3 \\
11 \\
4 \\
1 \\
3\end{array}$ \\
\hline Total & 82 & 18 & 29 & 129 & 110 & 4 & 5 & 119 & $248^{\star}$ \\
\hline
\end{tabular}

A, adult cardiology; P, paediatric cardiology; B, undertaking both adult and paediatric cardiology.

*The grand total of 248 physicians shown in the last column does not include two who retired between the index date of the survey and the end of 1982.

Neither method is accurate because the future cannot be known with certainty and intentions do change, but we believe the present method is probably a more useful estimate, at least as it applies to the next two or three years. The change in method accounts for small discrepancies compared with the 1981 publication but the pattern is very similar. The prospects for 1984 to 1987 are somewhat better for senior registrars, especially if posts new for the specialty become available at a rate similar to that since the original survey.

Table 3 shows the number of health districts without a cardiovascular physician. In this analysis, Wales created a minor anomaly in that it has twice as many major district general hospitals as health districts. The data are more comparable with those of England if the hospitals rather than districts are counted for the principality. A total of 63 "districts" serving a population of nearly 12 million evidently have no consultants meeting the definition of cardiovascular physicians made in this survey. We know from further inquiries that a few are well covered by visits from major centres; a few others have physicians well trained in the specialty but with commitments which preclude their spending $40 \%$ of their time in cardiology. But other health districts may well have inadequate provision for patients with heart disease which calls for specialist evaluation or treatment.

The number of senior registrars or equivalents (Table 4) available for consultant posts within the four years from our index date has decreased from 71 in the previous survey to 63 in this one. The distribution of these throughout the regions is shown in Table 5. In 1980, eight of the senior registrars were working in paediatric cardiology compared with seven in 1982. We know of one academic appointment which has been left vacant for economic reasons when the incumbent emigrated, but the major part of the fall must be due to the change in the number who are "time expired" or to a reduction in the number of posts funded from non-NHS or university sources with honorary senior registrar status. The ratio of consultants in post to senior registrars and equivalents (4:1) is now more favourable for those in training. 
Table 3 Number of health districts and populations without cardiovascular physicians working full time in specialty or with a major interest as defined for the survey

\begin{tabular}{|c|c|c|c|}
\hline Region and population & No of health districts in region & $\begin{array}{l}\text { No of health districts without } \\
\text { cardiovascular physicians }\end{array}$ & $\begin{array}{l}\text { Total health district population not } \\
\text { served by cardiovascular physicians }\end{array}$ \\
\hline $\begin{array}{l}\text { East Anglia } 1863100 \\
\text { Mersey } 2458000 \\
\text { Northern } 3078000 \\
\text { North East Thames } 3772000 \\
\text { North West Thames } 3460000 \\
\text { North Western } 4063000 \\
\text { Oxford } 2340000 \\
\text { South East Thames } 3544000 \\
\text { South West Thames } 2879000 \\
\text { South Western } 3029000 \\
\text { Trent } 4517000 \\
\text { Wessex } 2744000 \\
\text { West Midlands } 5161000 \\
\text { Yorkshire } 3577000 \\
\text { Wales } 2808 \text { 200 } \\
\text { National Heart and Chest and } \\
\text { Great Ormond Street Hospitals }\end{array}$ & $\begin{array}{l}8 \\
10 \\
16 \\
16 \\
15 \\
19 \\
8 \\
15 \\
13 \\
11 \\
12 \\
10 \\
22 \\
17 \\
9(18) \\
0 \quad 5\end{array}$ & $\begin{array}{l}3 \\
7 \\
7 \\
0 \\
3 \\
4 \\
2 \\
3 \\
5 \\
1 \\
3 \\
3 \\
6 \\
5 \\
3(11) \\
0\end{array}$ & $\begin{array}{r}708100 \\
1645000 \\
1198000 \\
\overline{697} 000 \\
738000 \\
390000 \\
758000 \\
1066000 \\
204000 \\
603000 \\
637000 \\
882000 \\
799000 \\
1399500 \\
-\end{array}$ \\
\hline Total & $206(215)$ & $55(63)$ & 11704500 \\
\hline
\end{tabular}

1 Wales has nine health districts and 18 district general hospitals, the figures in brackets refer to the district general hospitals.

2 Some health districts without cardiovascular physicians do have frequent visits from nearby cardiac centres.

^The National Heart and Chest Hospitals and Great Ormond Street do not comprise a region with districts. They are administered separately as independent special health authorities.

The data shown in Table 6 may give rise to some anxiety, but this information makes no allowance for appointments new to cardiology. It is reasonable to expect that some at least of the many health districts without cardiological expertise immediately available will seek to correct this deficiency. Moreover, some expansion in the consultant grade has occurred since these data were collected so that the excess of senior registrars may already have been reduced.

Technical support is very uneven through the regions (Table 7). East Anglia, Oxford, South East Thames, South West Thames, South Western, Wessex, and West Midlands regions are in the lower half of the ranking order, with Oxford and Wessex having the worst provision with only 0.55 technicians per 100000 population. Since physiological measurement technicians may be less willing than medical staff to move from one region to another, it must be a matter for concern that the most poorly endowed regions also tend to have least student technicians. The apparently large discrepancies in the numbers of cardiographers must be due in part to local variation in the extent to which physiological measurement technicians are expected to take electrocardiograms as part of their duties.

Few surprises emerged from the review of facilities by region shown in Table 8 . Major haemodynamic investigations were restricted, with a few exceptions, to centres with cardiac surgery-a policy supported by the joint report from the colleges of physicians and surgeons. ${ }^{2}$ Four regions (including Wales) had only one centre undertaking permanent pacemaker

Table 4 Senior registrars: contract expiry dates, type of appointment, and career intentions

\begin{tabular}{|c|c|c|c|c|c|c|c|c|c|}
\hline \multirow[t]{2}{*}{ Year } & \multirow[t]{2}{*}{ Number } & \multicolumn{3}{|c|}{ Type of appointment } & \multicolumn{5}{|c|}{ Career intentions } \\
\hline & & $N H S$ & Academic & Other & $\overline{W T}$ & $M I$ & $G M$ & $C A$ & $U D$ \\
\hline $\begin{array}{l}1982 \\
1983 \\
1984 \\
1985 \\
1986 \\
\text { No expiry date }\end{array}$ & $\begin{array}{r}8 \\
15 \\
15 \\
9 \\
6 \\
10\end{array}$ & $\begin{array}{r}5 \\
10 \\
10 \\
6 \\
5 \\
-\end{array}$ & $\begin{array}{l}1 \\
3 \\
5 \\
3 \\
1 \\
7\end{array}$ & $\frac{2}{2}$ & $\begin{array}{r}4 \\
11 \\
14 \\
6 \\
6 \\
4\end{array}$ & $\begin{array}{l}2 \\
3 \\
1 \\
- \\
1\end{array}$ & $\frac{-}{\frac{1}{2}}$ & $\frac{1}{\frac{1}{1}}$ & $\frac{1}{\frac{1}{2}}$ \\
\hline Total & $63 t$ & 36 & 20 & $8^{\star}$ & 45 & 7 & 3 & 4 & 4 \\
\hline
\end{tabular}

WT, whole time cardiology; MI, major interest cardiology; GM, general medicine (no special interest in cardiology); CA, career abroad; UD, undecided.

‡One senior registrar, whose contract expires in 1986, has both an "academic" and "other" appointment.

† One senior registrar, whose contract expires in 1986, has both an "academic" and "other" appointment. of these have academic appointments. 
Table 5 Number of full time cardiovascular physicians and senior registrars in post in each region at 1 fuly 1982

\begin{tabular}{|c|c|c|c|}
\hline Region & No of health districts & $\begin{array}{l}\text { Full time physicians in } \\
\text { cardiology }\end{array}$ & Senior registrars \\
\hline $\begin{array}{l}\text { East Anglia } \\
\text { Mersey } \\
\text { Northern } \\
\text { North East Thames } \\
\text { North West Thames } \\
\text { North Western } \\
\text { Oxford } \\
\text { South East Thames } \\
\text { South West Thames } \\
\text { South Western } \\
\text { Trent } \\
\text { Wessex } \\
\text { West Midlands } \\
\text { Yorkshire } \\
\text { Wales } \\
\text { National Heart and Chest Hospitals and }\end{array}$ & $\begin{array}{r}8 \\
10 \\
16 \\
16 \\
15 \\
19 \\
8 \\
15 \\
13 \\
11 \\
12 \\
10 \\
22 \\
17 \\
18\end{array}$ & $\begin{array}{r}3 \\
6 \\
9 \\
11 \\
14 \\
9 \\
3 \\
13 \\
5 \\
4 \\
5 \\
3 \\
12 \\
10 \\
4\end{array}$ & $\begin{array}{r}2 \\
2 \\
3 \\
9 \\
11 \\
2 \\
3 \\
4 \\
1 \\
3 \\
3 \\
0 \\
5 \\
6 \\
2\end{array}$ \\
\hline Great Ormond Street Hospital & 5 & 18 & 7 \\
\hline Totals & 215 & 129 & 63 \\
\hline
\end{tabular}

$\star$ Figure recorded for $W$ ales $=18$ district general hospitals.

Table 6 Comparison between senior registrars' contract expiry dates and cardiovascular physicians' retirement dates

\begin{tabular}{llll}
\hline Year & $\begin{array}{l}\text { No of contracts } \\
\text { expiring }\end{array}$ & $\begin{array}{l}\text { No of anticipated } \\
\text { retirements }\end{array}$ & Balance \\
\hline 1983 & 15 & 3 & -12 \\
1984 & 15 & 8 & -7 \\
1985 & 9 & 5 & -4 \\
1986 & 6 & 11 & +5 \\
No expiry date & 10 & - & -10 \\
\hline Total & 55 & 27 & -28 \\
\hline
\end{tabular}

The above figures take no account of posts new to the specialty that may be created over the next four years or of nine senior registrars who have obtained consultant posts since the survey. Of these, two had contracts that were due to expire in 1983, one in 1984, one in 1986 , and two had no contract expiry dates. The remaining three had contracts that expired in 1982. implantation. Inevitably this implies that many old and frail patients have to travel considerable distances either with temporary wires in situ or with the continuing risk of Adams-Stokes attacks. Of much greater concern, 42 health districts do not have facilities for temporary pacing (counting each major district hospital in Wales as a district for the reasons given above). This seems inappropriate since some forms of heart block constitute a grave emergency with a rewarding success rate only if facilities for treatment are immediately available. We also consider it disturbing that seven major centres were without a cross sectional echocardiograph in July 1982.

Facilities for stress testing were available in 185 of 215 districts, but 46 of these have only a bicycle

Table 7 Technical support in health regions in England and Wales

\begin{tabular}{|c|c|c|c|c|c|}
\hline \multirow[t]{2}{*}{ Region and population } & \multicolumn{4}{|c|}{ Physiological measurement technicians } & \multirow[t]{2}{*}{ Cardiographers } \\
\hline & Qualified & Students & Total & per 100000 & \\
\hline $\begin{array}{l}\text { East Anglia } 1863100 \\
\text { Mersey } 2458000 \\
\text { Northern } 3078000 \\
\text { North East Thames } 3772000 \\
\text { North West Thames } 3460000 \\
\text { North Western } 4063000 \\
\text { Oxford } 2340000 \\
\text { South East Thames } 3544000 \\
\text { South West Thames } 2879000 \\
\text { South Western } 3029000 \\
\text { Trent } 4517000 \\
\text { Wessex } 2744000 \\
\text { West Midlands } 5161000 \\
\text { Yorkshire } 3577000 \\
\text { Wales 2 808 200 } \\
\text { National Heart and Chest and } \\
\text { Great Ormond Street } \\
\text { Hospitals 0 }\end{array}$ & $\begin{array}{l}16.5 \\
48.2 \\
34.5 \\
44.8 \\
32.5 \\
85.0 \\
12.8 \\
34.1 \\
25.5 \\
26.3 \\
62.6 \\
12.0 \\
50.7 \\
54.1 \\
50.1 \\
\\
38.6\end{array}$ & $\begin{array}{r}3.0 \\
12.0 \\
9.5 \\
14.0 \\
15.5 \\
28.0 \\
0.0 \\
8.0 \\
8.0 \\
6.0 \\
14.5 \\
3.0 \\
10.0 \\
18.3 \\
21.5\end{array}$ & $\begin{array}{r}19.5 \\
60.2 \\
44.0 \\
58.8 \\
48.0 \\
113.0 \\
12.8 \\
42.1 \\
33.5 \\
32.3 \\
77.1 \\
15.0 \\
60.7 \\
72.4 \\
71.6\end{array}$ & $\begin{array}{l}1.05 \\
2.45 \\
1.43 \\
1.56 \\
1.39 \\
2.78 \\
0.55 \\
1.19 \\
1.16 \\
1.07 \\
1.71 \\
0.55 \\
1.18 \\
2.02 \\
2.55\end{array}$ & $\begin{array}{r}23.0 \\
3.2 \\
39.5 \\
35.8 \\
41.8 \\
32.5 \\
23.2 \\
47.9 \\
24.6 \\
30.7 \\
25.0 \\
24.0 \\
43.4 \\
27.0 \\
45.2\end{array}$ \\
\hline Total & 628.3 & $179 \cdot 3$ & $807 \cdot 6$ & - & 468.8 \\
\hline
\end{tabular}


Table 8 Summary of facilities in regions in England and Wales at 1 fuly 1982

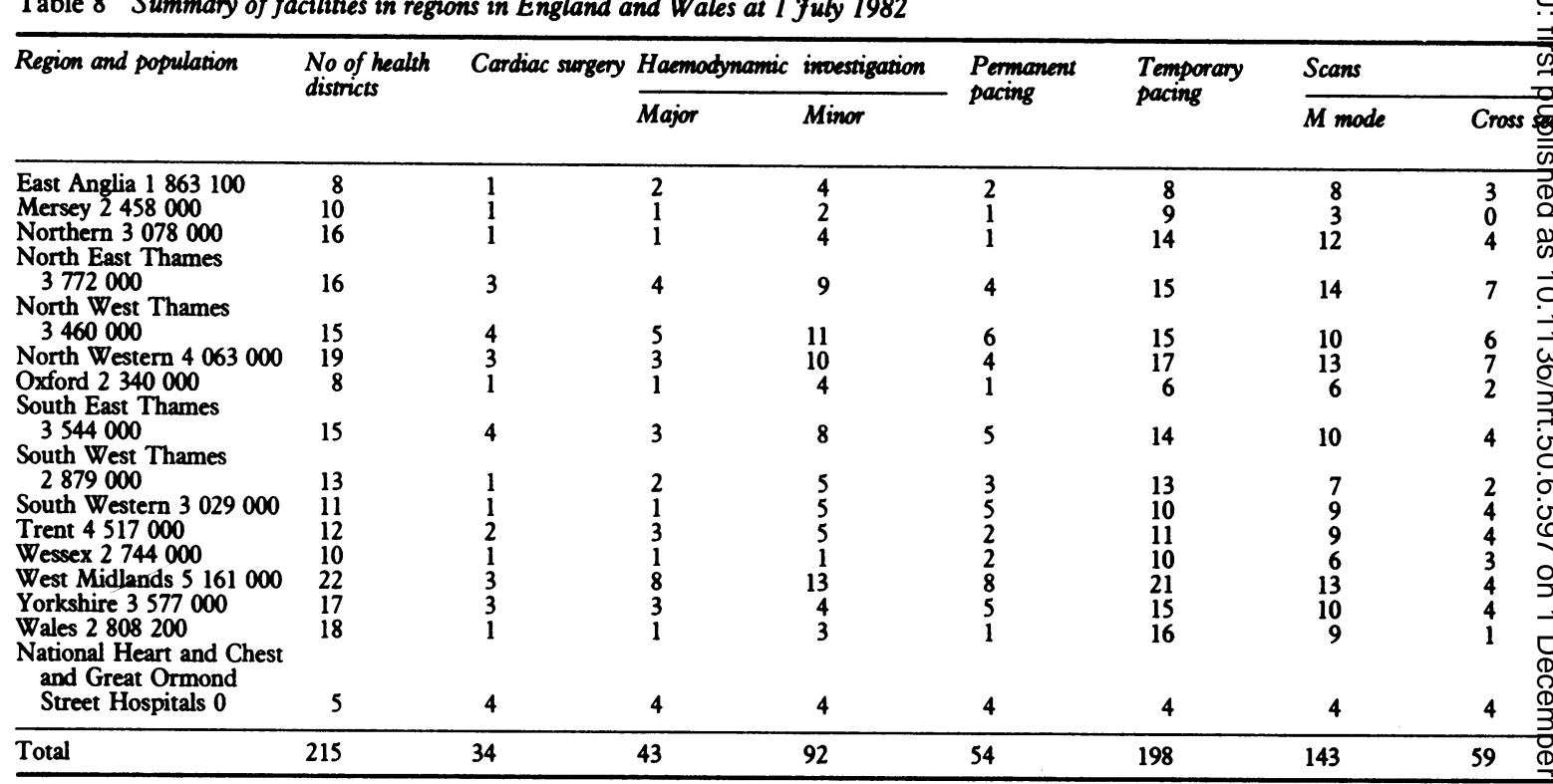

The figure that appears for Wales records district general hospitals; there are nine health districts.

* Monitored beds with a central console and immediate access to an image intensifier on the same floor.

tWithout immediate access to an image intensifier.

ergometer (usually, we believe, without any means of setting a work load in a reproducible fashion). Excluding the postgraduate institutions in London, 76 districts had no cardiac care units-using the strict definition ${ }^{3}$ of monitored beds with immediate access to image intensification facilities. Most of these, however, did have monitored beds without an image intensifier. Coronary or resuscitation ambulances are available in only 21 districts.

The previous report drew attention to the relative underprovision for cardiology in England and Wales: most EEC countries at that time had two to 10 times more cardiologists, in relation to population figures, than we had. A little progress has been made since then though not enough materially to influence this ratio. The expertise of fully trained senior registrars

Appendix I Number of cardiovascular physicians in health boards of Scotland

\begin{tabular}{|c|c|c|c|c|c|c|c|}
\hline \multirow[t]{2}{*}{ Health board } & \multicolumn{3}{|c|}{$\begin{array}{l}\text { Physicians } \\
\text { Full time cardiology }\end{array}$} & \multicolumn{3}{|c|}{$\begin{array}{l}\text { Physicians } \\
\text { Major interest }\end{array}$} & \multirow[t]{2}{*}{$\begin{array}{l}\text { No of physicians } \\
\text { engaged in cardiology }\end{array}$} \\
\hline & Adult & Paediatric & Both & Adult & Paediatric & Both & \\
\hline Argyll and Clyde & - & - & - & - & - & - & - \\
\hline Ayrshire and Arran & - & - & - & 2 & - & - & 2 \\
\hline $\begin{array}{l}\text { Borders } \\
\text { Dumfries and }\end{array}$ & - & - & - & - & - & - & - \\
\hline Galloway & - & - & - & 2 & - & 一 & 2 \\
\hline Fife & - & - & - & 1 & - & - & 1 \\
\hline Forth Valley & - & - & - & - & - & - & \\
\hline Grampian & & E & - & 1 & $\overline{2}$ & 1 & $2^{3}$ \\
\hline $\begin{array}{l}\text { Greater Glasgow } \\
\text { Highland }\end{array}$ & $\underline{9}$ & $\bar{z}$ & $\overline{-}$ & $\underline{9}$ & 2 & $\overline{1}$ & 20 \\
\hline $\begin{array}{l}\text { Highland } \\
\text { Lanarkshire }\end{array}$ & $\overline{-}$ & - & Z & 2 & 三 & 1 & $\begin{array}{l}1 \\
2\end{array}$ \\
\hline Lothian & $\overline{4}$ & $\overline{1}$ & - & 1 & - & - & 6 \\
\hline Orkney & - & - & - & - & - & - & - \\
\hline Shetland & - & - & - & - & - & - & $\overline{3}$ \\
\hline Tayside & - & - & 1 & 2 & - & - & 3 \\
\hline Western Isles & - & 一 & - & - & 一 & - & 一 \\
\hline Total & 14 & 1 & 1 & 20 & 2 & 2 & 40 \\
\hline
\end{tabular}




\begin{tabular}{|c|c|c|c|c|c|c|c|}
\hline \multirow[t]{2}{*}{ ntigraphy } & \multirow{2}{*}{$\begin{array}{l}\text { Invasive } \\
\text { electrophysiology }\end{array}$} & \multicolumn{2}{|c|}{ Ambulatory monitoring } & \multirow{2}{*}{$\begin{array}{l}\text { Stress test } \\
\text { (treadmill or bicycle) }\end{array}$} & \multirow[t]{2}{*}{ Cardiac care unit ${ }^{\star}$} & \multirow[t]{2}{*}{ Monitored bedst } & \multirow{2}{*}{$\begin{array}{l}\text { Coronary } \\
\text { ambulance }\end{array}$} \\
\hline & & $\begin{array}{l}\text { Recording } \\
\text { facilities only }\end{array}$ & $\begin{array}{l}\text { Recording } \\
\text { facilities and analysis }\end{array}$ & & & & \\
\hline & $\begin{array}{l}0 \\
1 \\
2\end{array}$ & $\begin{array}{r}7 \\
6 \\
15\end{array}$ & $\begin{array}{l}3 \\
1 \\
6\end{array}$ & $\begin{array}{r}7 \\
7 \\
14\end{array}$ & $\begin{array}{r}5 \\
5 \\
12\end{array}$ & $\begin{array}{l}3 \\
4 \\
3\end{array}$ & $\begin{array}{l}0 \\
1 \\
1\end{array}$ \\
\hline & 4 & 15 & 12 & 16 & 11 & 5 & 1 \\
\hline & $\begin{array}{l}5 \\
4 \\
1\end{array}$ & $\begin{array}{r}14 \\
16 \\
7\end{array}$ & $\begin{array}{r}11 \\
15 \\
6\end{array}$ & $\begin{array}{r}11 \\
16 \\
7\end{array}$ & $\begin{array}{r}13 \\
17 \\
3\end{array}$ & $\begin{array}{l}3 \\
3 \\
4\end{array}$ & $\begin{array}{l}0 \\
2 \\
1\end{array}$ \\
\hline & 4 & 13 & 11 & 15 & 13 & 5 & 2 \\
\hline $\begin{array}{l}\vdots \\
\vdots \\
\vdots\end{array}$ & $\begin{array}{l}2 \\
3 \\
3 \\
1 \\
5 \\
2 \\
1\end{array}$ & $\begin{array}{l}11 \\
11 \\
10 \\
10 \\
22 \\
14 \\
13\end{array}$ & $\begin{array}{r}8 \\
8 \\
9 \\
5 \\
13 \\
11 \\
10\end{array}$ & $\begin{array}{l}13 \\
10 \\
11 \\
10 \\
17 \\
14 \\
12\end{array}$ & $\begin{array}{r}10 \\
10 \\
14 \\
8 \\
20 \\
10 \\
9\end{array}$ & $\begin{array}{l}3 \\
1 \\
2 \\
4 \\
3 \\
6 \\
8\end{array}$ & $\begin{array}{l}4 \\
3 \\
1 \\
2 \\
2 \\
1 \\
0\end{array}$ \\
\hline i & 4 & 4 & 4 & 4 & 2 & 2 & 0 \\
\hline ? & 42 & 188 & 133 & 185 & 162 & 59 & 21 \\
\hline
\end{tabular}

who have not found consultant appointments represents an asset which is being wasted while many districts have pressing need for their service.

\section{Conclusion}

Large numbers of people in Britain do not readily have access to the many new techniques for investigation and up to date treatment which can improve the quality and increase the duration of life. We do not believe that the uneven provision for heart disease can be justified; we hope that the data provided in this report will not only be of interest to physicians within the specialty but will also assist those with responsibility of planning resources for health care.

We thank Dr Martin Daniels for the time and effort he has devoted to writing very complex computer programs to enable us to complete this survey and monitor future trends. We also thank $\mathrm{Dr}$ David Ballantyne and Dr Dennis Boyle for providing us with data relating to Scotland and Northern Ireland for inclusion in the appendices.

Appendix II Number of cardiovascular physicians in Northern Ireland

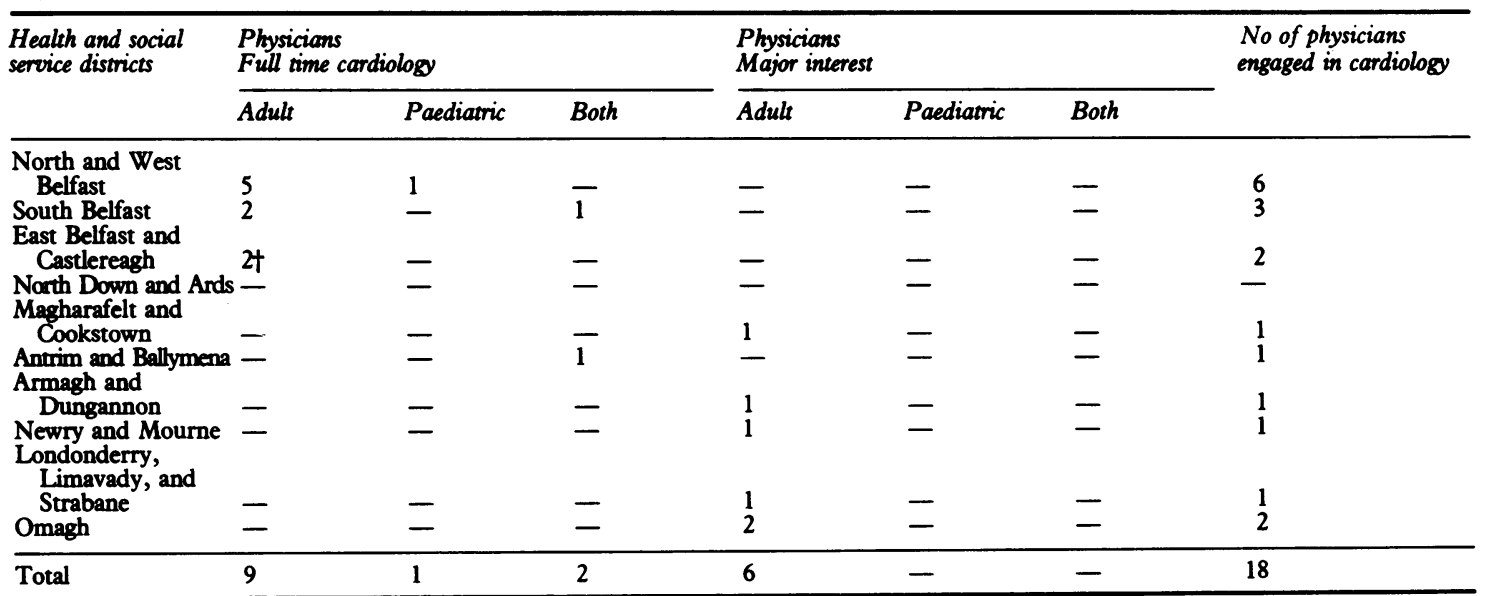

†Both also work in another district: one in North Down and Ards and the other in North and West Belfast. 


\section{References}

1 Chamberlain DA, Goodwin JF, Emanuel RW, Bailey LG. Career prospects in cardiology in England and Wales. Survey of 15 health regions. Br Heart $\mathcal{f} 1981$; 45: 460-3.

2 Joint Cardiology Committee of the Royal College of Physicians of London and the Royal College of Surgeons of England. Second report on combined cardiac centres for investigation and treatment with a note on the requirements of cardiology in hospital outside such a centre. Br Heart f 1980; 43: 211-9.

3 Royal College of Physicians of London and the British Cardiac Society. The care of the patient with coronary heart disease. Report of the joint working party. $f R$ Coll Physicians Lond 1975; 10: 5-46.

Requests for reprints to the Secretary of the British Cardiac Society, 2 Beaumont Street, London W1N 2DX. 